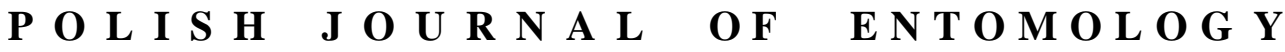

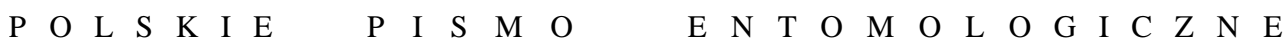

VOL. 83: 201-206

Lublin

30 September 2014

DOI: $10.2478 /$ pjen-2014-0015

\section{Chalybion omissum (KoHL, 1889) (Hymenoptera: Sphecidae, Sceliphrini): new records from the Balkan Peninsula (southern Bulgaria)}

\section{PIOTR OLSZEWSKI ${ }^{1}$, TOSHKO LJUBOMIROV ${ }^{2}$, TADEUSZ PAWLIKOWSKI ${ }^{1}$, TADEUSZ BARCZAK ${ }^{3}$}

\footnotetext{
${ }^{1}$ Chair of Ecology and Biogeography, Nicolaus Copernicus University, Lwowska 1,87-100 Toruń, Poland; e-mails: thecla@wp.pl,pawlik@biol.uni.torun.pl ${ }^{2}$ Institute of Biodiversity and Ecosystem Research, Tzar Osvoboditel Boulevard, Sofia 1000, Bulgaria; e-mail: toshkoljubomirov@gmail.com ${ }^{3}$ Department of Zoology, University of Technology and Life Sciences, Kordeckiego 20, 85-225 Bydgoszcz, Poland; e-mail: tadbar@utp.edu.pl
}

\begin{abstract}
The paper presents new information about the occurrence of Chalybion omissum (KoHL, 1889) in central part of Balkan Peninsula (southern Bulgaria). Seven specimens were caught at 4 sites: $\mathrm{N}$ of Kurdzhali (UTM: LG61), Usstrem village (MG55), NE of Kalimantsi village (GL09), NE of Madzharovo (MG01).
\end{abstract}

KEY WORDS: Hymenoptera, Sphecidae, Chalybion omissum, new records, Balkan Peninsula.

\section{INTRODUCTION}

A total of 46 species have been described to date in the genus Chalybion DAHLBOM, 1843. Their highest diversity occurs in the Old World. In Europe, 6 species have been recorded (BOHART \& MENKE 1976, MEI et al. 2012, PUlAWSKI 2013), including Chalybion bengalense (DAHLBOM, 1845), which was brought to Europe from the Oriental realm (the Indomalayan ecozone) as a result of human activity (MEI et al. 2012). 
Species from the genus Chalybion are of average or large body size, ranging from 11 to $32 \mathrm{~mm}$. Their body is blue or dark metallic blue, hence they resemble species from the genera Stangeella MENKE, 1962 and Chlorion LATREILLE, 1809. They differ, however, in the wing venation (BOHART \& MENKE 1984). The forewings of the genus Chalybion have two discoidal cells, and both recurrent veins join the second submarginal cell (BOHART \& MENKE 1976). Furthermore, the genus is distinguished by the dorsal region, referred to as the propodeum, without a U-shaped edge, and the equal length of the third and the fourth segment of the flagellum (HENSEN 1988).

\section{MATERIAL AND METHODS}

Specimens of Chalybion omissum (KOHL, 1889) were collected using entomological nets, yellow bowls and a Malaise trap in four different localities in southern Bulgaria (Fig. $1)$.

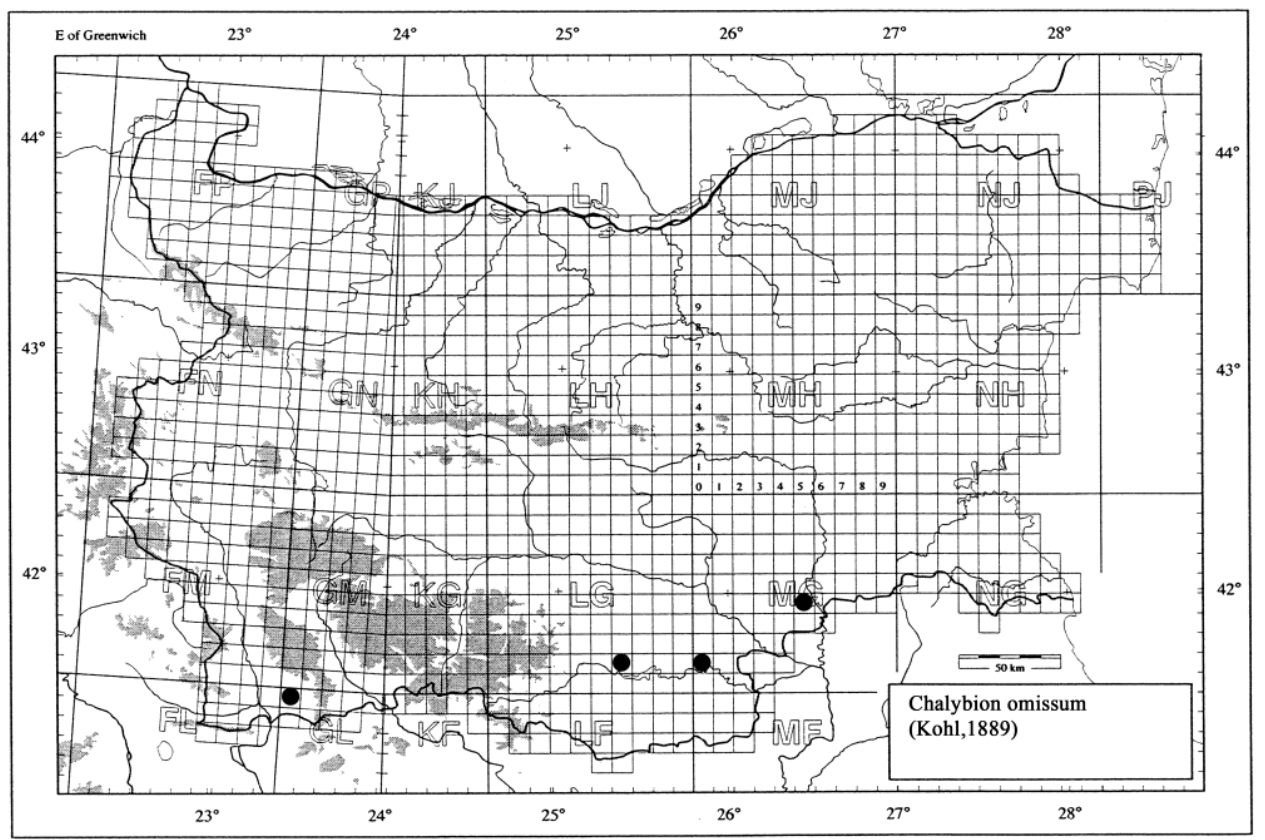

Fig. 1. Distribution of Chalybion omissum in Bulgaria. 


\section{RESULTS AND DISCUSSION}

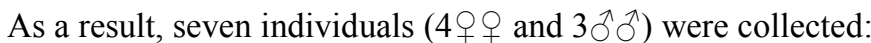

- xerothermic mountain slope of the Arda river valley $\left(41^{\circ} 39^{\prime} 8^{\prime \prime} \mathrm{N}, 25^{\circ} 22^{\prime} 21^{\prime \prime} \mathrm{E}\right.$, UTM: LG61), 25 VI 1980 - 1 q (Fig. 2), entomological net, T. BARCZAK leg.

- Usstrem village, Tundzha river valley (42॰01'24”N, 26²7’40”E, MG55), 23 V 1995 $2 \hat{\jmath}$, Moericke trap, I. STOYANOv leg.

- NE of Kalimantsi village, southern foothills of Pirin Mountain $\left(41^{\circ} 27^{\prime} 51.88^{\prime \prime} \mathrm{N}\right.$,

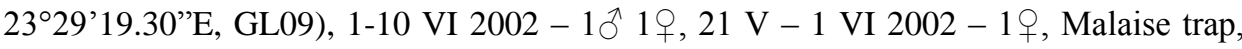
M. LANGOUROV leg.

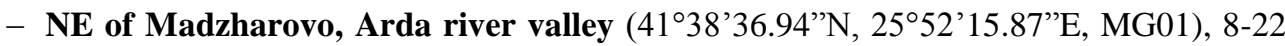
VI $2001-1$, Malaise trap, H. ETURSKA leg.

Chalybion omissum is known mainly from the south-central and southern parts of Europe. This species is reported from Albania, Croatia, Serbia, Greece, Italy, Slovenia, the western half of Asiatic Turkey and Israel (BAYINDIR et al. 2013; BITSCH 2010; DE BEAUMONT 1965, 1967; Gogala 2011; GÜlMEZ \& TÜZÜN 2005; HeNSEN 1988; JóZAN 2009; LJubomirov \& Yildirim 2008; MAIDL 1922; MocsáRY 1897; PAGLIANo 2009; SCHLETTERER 1894; STANDFUSS \& STANDFUSS 2006; SZILÁDY 1914; YILDIRIM 2014).

The morphological characteristics of $C$. omissum were presented by HENSEN (1988). The dorsal surface of the propodeum is transversely striate (Fig. 3a). The important feature in C. omissum females is the presence of a large patch of micropubescence on the posterior half of sternite 4 , which distinguishes it from the morphologically related $C$. bengalense (DAHLBOM, 1845).

The female differs from the closely related $C$. japonicum (GRIBODO, 1883) in the metasomal sternum 1 almost straight in the lateral view (rather than strongly curved) and from C. turanicum (GUSSAKOVSKIJ, 1935) in the median lobe of the clypeal free margin, which is much narrower than the submedian lobe (Fig. 3b) (rather than about as wide as the submedian lobes) and by the presence of a basal tooth on the hind tarsal claw.

The male of $C$. omissum is unique in having the following combination of characters: eighth metasomal sternite narrow (Fig. 3c), metasomal sternum 1 almost straight in the lateral view and shorter than hind basitarsus and flagellomeres 8- 9 only.

Females of all species of Chalybion prey on spiders and place them in their nests as food for larvae. They build nests in abandoned larval galleries in the woody stems of plants, wall crevices, or abandoned nests of other Apoidea e.g. Sceliphron KLUG, 1801 or Trypoxylon LATREILle, 1796 (BOHART \& MENKE 1976; MeI et al. 2012). They use mud for building walls inside a nest or for sealing. The method of constructing nests is similar to that of Sceliphron, except that water is first brought to the place from where the building 
material is collected. They lay their eggs on the spider's abdomen (BOHART \& MENKE 1976) and they often form of imagines clusters in adverse weather conditions.

Since the beginning of the $21^{\text {st }}$ century, a growing number of localities of C. omissum in Europe has been recorded. The species nests in sheltered places, often on human artifacts, enabling its easy transport over considerable distances (MEI et al. 2012). This may partly explain its frequent occurrence in urban areas.

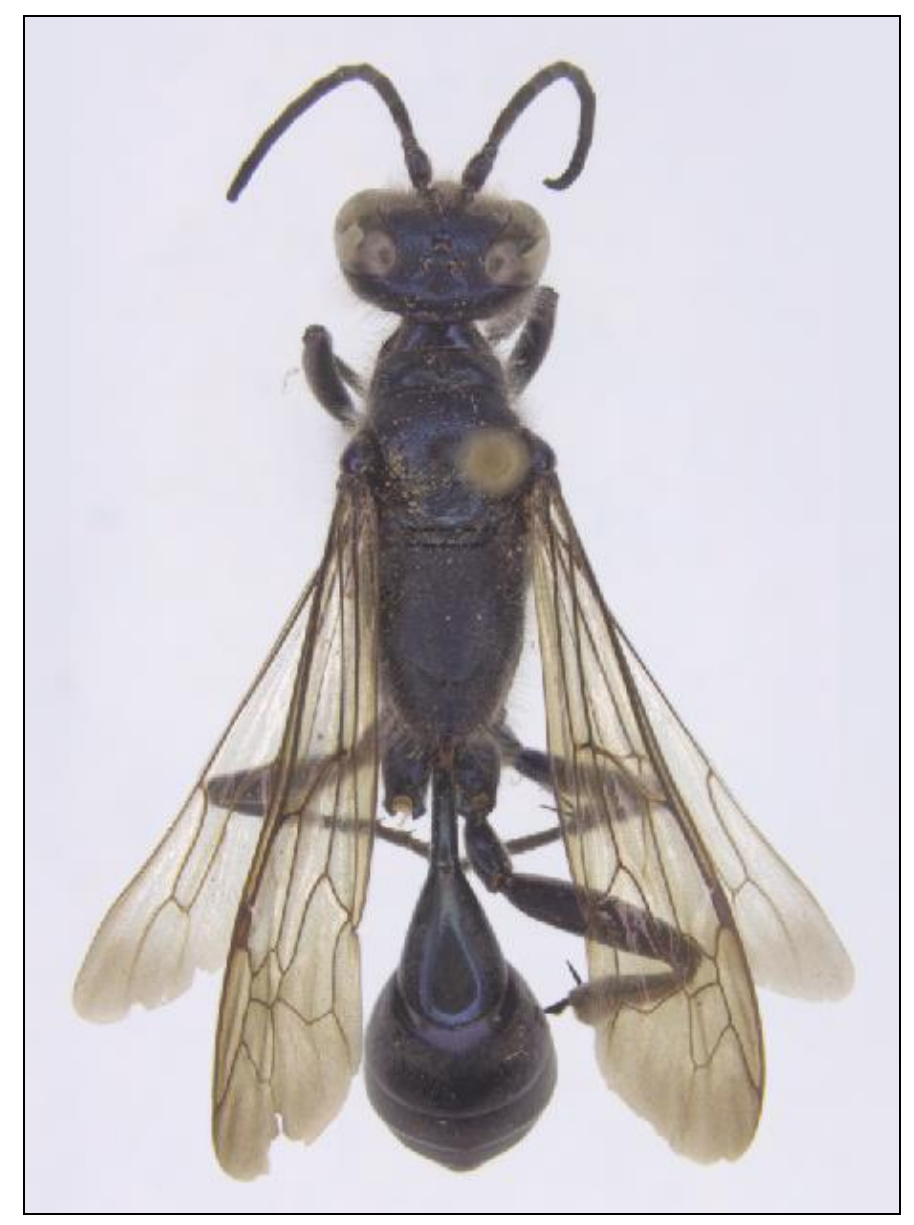

Fig. 2. Habitus of female Chalybion omissum, dorsal view. 

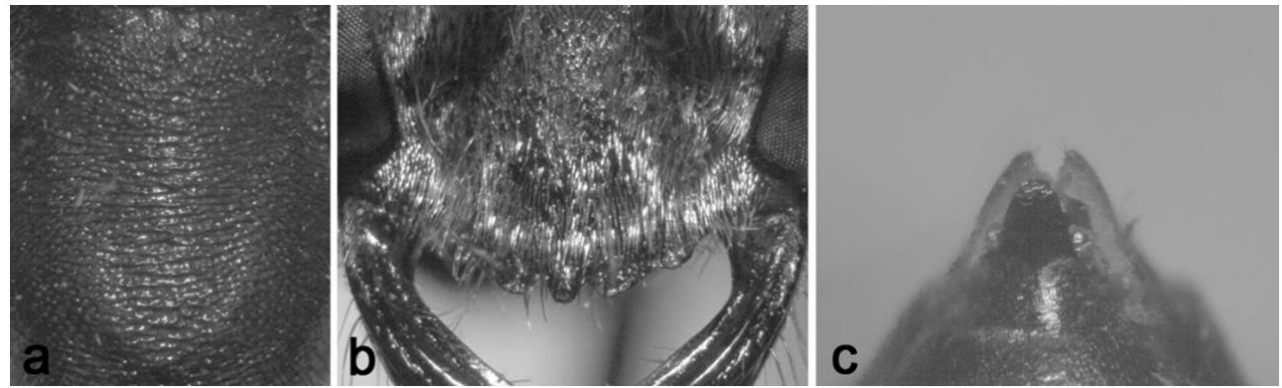

Fig. 3. Chalybion omissum: male propodeum (a); female clypeus (b); male eighth sternite (c).

\section{ACKNOWLEDGEMENTS}

We would like to express our cordial thanks to Ms H. EtURSKA, Mr M. LANGOUROV and Mr I. Stoyanov for providing the material. We are grateful to Prof. K. SzPILA and Dr A. GRZYwaCZ (Nicolaus Copernicus University, Toruń) for their help with taking the photographs.

\section{REFERENCES}

BAyindir A., GÜRbÜz M.F., LjubOMirov T., PoHL D. 2013. Diversity of digger wasps in Kasnak Oak Forest Nature Reserve, Isparta, Turkey, with records of eight species new to Turkey (Hymenoptera: Sphecidae, Crabronidae and Ampulicidae). Zoology in the Middle East 59(2): 144-147.

Bohart R.M., Menke A.S. 1976. Sphecid Wasps of the World. A generic revision. University of California Press, Berkeley - Los Angeles - London.

BitsCH J. 2010. Compléments au volume 2 des Hyménoptères Sphecidae d'Europe occidentale (Faune de France 82). Bulletin de la Société entomologique de France 115(1): 99-136.

de Beaumont J. 1965. Les Sphecidae de la Grèce (Hym.). Mitteilungen der Schweizerischen Entomologischen Gesellschaft 38: 1-65.

DE Beaumont J. 1967. Hymenoptera from Turkey. Sphecidae, I. With Appendix. Sphex Linné, Subgenus Palmodes KoHL par P. RотH. Bulletin of the British Museum (Natural History). Entomology 19(5): 253-382.

Gogala A. 2011. Sphecid wasps of Slovenia (Hymenoptera: Ampulicidae, Sphecidae and Crabronidae). Scopolia 73: 1-39.

GÜLMEZ Y., TÜZÜN A. 2005. Spheciformes (Hymenoptera: Apoidea) from Ankara Province, subfamilies: Sphecinae, Pemphredoninae and Astatinae. Journal of the Entomological Research Society 7(1): 41-57. 
HENSEN R.V. 1988. Revision of the nominate subgenus Chalybion DAHLBOM (Hymenoptera, Sphecidae). Tijdschrift voor Entomologie 131: 13-64.

Ljubomirov T. \& YiLdiRim E. 2008. Annotated catalogue of the Ampulicidae, Sphecidae, and Crabronidae (Insecta: Hymenoptera) of Turkey. Pensoft Press, Sofia.

JózAN Z. 2009. Contribution to the knowledge of the Croatian Aculeata fauna (Hymenoptera: Aculeata). Natura Somogyiensis 15: 159-180.

MAIDL F. 1922. Beiträge zur Hymenopterenfauna Dalmatiens, Montenegros und Albaniens. Annalen des Naturhistorischen Museums in Wien 35: 36-106.

Mei M., Pezzi G., De Togni R., Devincenzo U. 2012. The Oriental mud-dauber wasp Chalybion bengalense (DAHLBOM) introduced in Italy (Hymenoptera, Sphecidae). Ampulex 5: 37-41.

MocsÁRY A. 1897. Ordo Hymenoptera. In: A. MocsÁRy (ed.). Fauna Regni Hungariae. III. Arthropoda (Insecta. Hymenoptera). Királyi Magyar Természettudományi Társulat, Budapest, $7-116$.

PAGLiAno G. 2009. Unpublished data of Sphecidae (Hymenoptera) in Piedmont and other Italian areas. Rivista Piemontese di Storia Naturale 30: 173-192.

Pulawski W. 2013. Sphecidae sensu lato (= Apoidea excluding Apidae). Internet: http://research.calacademy.org/ent/catalog_sphecidae/

SCHLETTERER A. 1894. Zur Hymenopteren-Fauna Istriens. Jahresberichte des k.k. Staatsgymnasiums von Pola 4: 1-35.

Standfuss K., Standfuss L. 2006. Zum aktuellen Artenbestand der Pemphredoninae, Bembicinae und Sphecinae (Hymenoptera: Crabronidae p.p. et Sphecidae) der planar-kollinen Vegetationsstufe in Südost Thessalien-Griechenland. Entomofauna 27(26): 301-316.

SZILÁDY Z. 1914. Verzeichniss meiner Insektenansammlungen in Ungarn. III. Hymenoptera.. Rovartani Lapok 21(4-8): 78-95. (in Hungarian)

YILDIRIM E. 2014. Overview of the distribution and biogeography of Sphecidae in Turkey (Hymenoptera: Aculeata). Entomologie faunistique - Faunistic Entomology 67: 27-36.

Received: 13 May 2014

Accepted: 30 May 2014 